\title{
THE RELATIONSHIP BETWEEN STUDENTS' MOTIVATION AND THEIR LEARNING ACHIEVEMENT
}

\author{
Dian Rosmayanti ${ }^{1}$, Hilva Yanuarti ${ }^{2}$ \\ ${ }^{1}$ IKIP Siliwangi \\ ${ }^{2}$ IKIP Siliwangi \\ ${ }^{1}$ diianrosmayanti@gmail.com, ${ }^{2}$ hilvayanuarti@gmail.com
}

\begin{abstract}
Among the factor influencing students learning, motivation becomes one of the momentous factors that may affect students learning achievement. The aim of this study is to investigate the relationship between students' motivation and their learning achievement. The subject were 88 second year students at Science major class of an Islamic high school in Cimahi City in the second semester of the Academic year 2018. The research uses quantitative corelation as a method consisting of two variables, namely students motivation (independent) and students achievement (dependent). The writers uses questionnaire as an instrument to collect the data and the student English score from their English teacher. The data analyze use SPSS. Finding from this study indicate that there are any relationship between students motivation and their learning achievement. The relationship between students' motivation and their English learning achievement was significantly and has Medium Correlation. When the result showing 0.580 appropriate with Pearson Correlation degree Value $0.41 \mathrm{~s} / \mathrm{d} 0.60=$ Medium Correlation.
\end{abstract}

Keywords: Relationship, Motivation, Achievement

\section{INTRODUCTION}

English language as an International language which that many people all the world used English for communicate. The term English as an International Language (EIL) was first proposed by (Smith, 1976) as cited by (Nicholson, 2015) defined as a language that is used between members who come from different " linguacultures". In Indonesia itself English language is as a foreign language that means the language is not used to communicate in their regularly activities but is taught in classrooms. English language is taught since Elementary School until Collage.

Learning English language at Elementary school until High school in Indonesia is usually done once or twice a week for an hour or two each time. With the limited that time making students have a limited abilities in speaking, reading writing or understanding the English language. In language acquisition process, learning in weeks results in pretty little achievement. In addition to the limited factor of learning English in school, another factor of the lack of students' mastery of English is that they hardly find english-speaking community in their environment (Panggabean, 2015). Further, he argue that a native speaker get his language because he keeps learning by thinking, listening, and speaking in the language he is learning, meaning, he learns the language regularly and many students in Indonesia do not realize how momentous the English language for their future (Panggabean, 2007). 
According to (Suprijono, 2009) that motivation to learn is the process that gives the spirit of learning, direction, and persistence of behavior (Asvio, N. Arpinus, 2017). To increase learning motivation (Makmum, 2000) states that we can identify some indicators in certain stages. There are eight kinds of indicators of motivation :1) the duration of the activity;2) the frequency of the activity; 3) persintence of the objectives of the activity: 4) fortitude, tenacity and ability in the face of actions and difficulties to achieve the objectives; 5) devotion and sacrifice to achieve aims; 6) the level of aspirations to be achieved by the activities carried out; 7) the level of qualification achievement; and 8) toward its attitude toward the target activity. (Ellliot, A. J., \& Covington, 2001) as cited by (Alizadeh, 2016) claims motivation gives the reasons for peoples' action, desire, and need. Kaswan \& Suprijadi (2014) stated the importance of activating learners' motivation :" The truth of the matter is that 99 percent of teaching is making the students feel interested in the material.". Motivation is distinguished into two type:

Intrumental motivation :Wanting to learn a language because it will be useful for certain instrumental goals, such as getting a job, passing an examination, etc.

Integrative motivation :Wanting to learn a language in order to communicate with people of another culture who speak it.

Learning motivation is an momentous field in language pedagogy since it is seen as one of the key variables contributing to go the successful acquisition of foreign language or second language (Kormos, J. \& Cszier, 2010) as cited by (Choosri, C., \& Intharaksa, 2011). Students motivation can influence their English language achievement.

Learning achievement is the outcome a person gain when doing certain tasks or activities (Tu'u, 2004) as cited by (Asvio, N. Arpinus, 2017). Their argue it is the acquisition of knowledge or skills developed by the subjects, usually indicated by test scores or number grades given by teacher. According to (Poerwanto, 2007) that learning achievement is result someone achieved in learning as stated in the report card, Furthermore, (Winkel, 2003) states that learning achievement is a testament to the success of students in the learning or someone's ability in doing learning activities in accordance with the quality gained as cited by (Asvio, N. Arpinus, 2017).

Many studies have done research about motivation for example in Thailand by Chalermporn Choosri and Usa Intharaksa the that subject: Relationship between Motivation and Students' English learning Achievement: A study of the second -year vocational certificate level Hatyai Technical Collage Students performance that motivation has helpful correlation with student's English achievement. The lack in the motivation and learning achievement has been additional motive to investigate these factor. It is the writers meaning conducting this study to research and report the relationship between motivation and student's achievement.

\section{METHOD}

According to (Leedy, 1993) quantitative research methods are dealing with number and anything that is measurable in a systematic way of investigation of phenomena and their relationship, it is use to answer question or relationship within measurable variables with an intention to explain, predict and control phenomena. consisting of two variables, namely students motivation (independent) and students achievement (dependent). The respondent of this study are 88 students of grade XI Science Major. The instrument was questionniare (see Table 1) which was adopted from Choosri, C., \& Intharaksa, 2011), The questionnaire was divided into 2 parts. The first part consisted of 17 items asking about instrumental motivation goals such as in receipt of a job, momentary an examination) in English learning and the second 
parts consisted of 8 items asked about integrative motivation in English learning. The questionnaire was deliberate by a 5 -point likert scale ( $1=$ strongly disagree; $5=$ strongly agree) (Gao, Et.al. 2007) as cited by (Choosri, C., \& Intharaksa, 2011). The questionnaire was translated into Bahasa Indonesia in command to easily for respondents understood the questionnaire. Respondents were required to choose a number on a 5-point Likert scale base on their own answer. The writer also used document, is the list of students English score from their English teacher. The data analysis the writer used Pearson Formula in SPSS.

Table 1. Questionnaire

\begin{tabular}{|c|c|c|c|c|c|c|}
\hline No & Question & $\begin{array}{l}\text { Strongly } \\
\text { Agree }\end{array}$ & Agree & $\begin{array}{c}\text { Less } \\
\text { Agree }\end{array}$ & Disagree & $\begin{array}{l}\text { Strongly } \\
\text { Disagree }\end{array}$ \\
\hline 1 & $\begin{array}{l}\text { I have to use English in } \\
\text { my future career. }\end{array}$ & & & & & \\
\hline 2 & $\begin{array}{l}\text { I want to get good } \\
\text { position. }\end{array}$ & & & & & \\
\hline 3 & $\begin{array}{l}\text { I want to get good } \\
\text { income. }\end{array}$ & & & & & \\
\hline 4 & $\begin{array}{l}\text { I want to broaden my } \\
\text { knowledge. }\end{array}$ & & & & & \\
\hline 5 & $\begin{array}{l}\text { I want to know and } \\
\text { communicate with } \\
\text { foreigners. }\end{array}$ & & & & & \\
\hline 6 & $\begin{array}{l}\text { I want to learn various } \\
\text { events around the world. }\end{array}$ & & & & & \\
\hline 7 & I can read textbook. & & & & & \\
\hline 8 & $\begin{array}{l}\text { I can understand English } \\
\text { movie, video or radio } \\
\text { program. }\end{array}$ & & & & & \\
\hline 9 & $\begin{array}{l}\text { I want to search for } \\
\text { English information on } \\
\text { the internet. }\end{array}$ & & & & & \\
\hline 10 & I want to get good grade. & & & & & \\
\hline 11 & $\begin{array}{l}\text { I want to further my } \\
\text { study. }\end{array}$ & & & & & \\
\hline 12 & $\begin{array}{l}\text { I want to travel to } \\
\text { English speaking } \\
\text { countries. }\end{array}$ & & & & & \\
\hline 13 & $\begin{array}{l}\text { Learning English make } \\
\text { me feel happy. }\end{array}$ & & & & & \\
\hline 14 & $\begin{array}{l}\text { Learning English can } \\
\text { give me a sense of } \\
\text { achievement. }\end{array}$ & & & & & \\
\hline 15 & $\begin{array}{l}\text { The knowledge in } \\
\text { English can enhance the } \\
\text { achievement in various } \\
\text { aspects. }\end{array}$ & & & & & \\
\hline
\end{tabular}




\begin{tabular}{|c|c|}
\hline 16 & $\begin{array}{l}\text { Other people will respect } \\
\text { me more if I know } \\
\text { English. }\end{array}$ \\
\hline 17 & $\begin{array}{l}\text { An educated person is } \\
\text { supposed to be able to } \\
\text { speak English. }\end{array}$ \\
\hline 18 & $\begin{array}{l}\text { I want to be a part of } \\
\text { English - speaking } \\
\text { groups. }\end{array}$ \\
\hline 19 & $\begin{array}{l}\text { I want to keep in touch } \\
\text { with foreign friends and } \\
\text { acquaintance }\end{array}$ \\
\hline 20 & $\begin{array}{l}\text { I want to learn about } \\
\text { foreigners' lifestyle in } \\
\text { English speaking } \\
\text { countries. }\end{array}$ \\
\hline 21 & $\begin{array}{l}\text { The more I get to know } \\
\text { native speakers, the more } \\
\text { I like/ appreciate them. }\end{array}$ \\
\hline 22 & $\begin{array}{l}\text { I want to learn their } \\
\text { culture and various } \\
\text { English speaking people. }\end{array}$ \\
\hline 23 & $\begin{array}{l}\text { I want to participate in } \\
\text { the activities of other } \\
\text { cultural groups. }\end{array}$ \\
\hline 24 & $\begin{array}{l}\text { I want to understand } \\
\text { English arts, literatures } \\
\text { and history. }\end{array}$ \\
\hline 25 & $\begin{array}{l}\text { I want to understand the } \\
\text { relation between } \\
\text { languages, cultures and } \\
\text { native speakers' } \\
\text { lifestyles. }\end{array}$ \\
\hline
\end{tabular}

Table 2. Value of Catagory in Questionnaire

\begin{tabular}{cc}
\hline Category & Value \\
\hline Strongly Agree & 5 \\
\hline Agree & 4 \\
\hline Less Agree & 3 \\
\hline Disagree & 2 \\
\hline Strongly Disagree & 1 \\
\hline
\end{tabular}

\section{RESULTS AND DISCUSSION}

\section{Results}

To get the data the writers used questionnaire consist of question about students motivation toward English Language. 
To know the relationship between motivation and students' learning achievement the writer calculated the data between questionnaire and a list of students English score from their English teacher used pearson data analysis used SPSS Formula. The result is listed in table 2

Table 3.

\begin{tabular}{llrr}
\hline \multicolumn{3}{c}{ Correlations } \\
\hline \multirow{2}{*}{ motivation } & Motivation & Achievement \\
\cline { 1 - 3 } & Pearson Correlation & 1 & $.580^{* *}$ \\
& Sig. (2-tailed) & & .000 \\
& $\mathrm{~N}$ & 88 & 88 \\
\hline achievement & Pearson Correlation & $.580^{* *}$ & 1 \\
& Sig. (2-tailed) & .000 & \\
& $\mathrm{~N}$ & 88 & 88 \\
\hline${ }^{* *}$. Correlation is significant at the 0.01 level (2-tailed).
\end{tabular}

Based on the Table 3. There are any relationship between students' motivation and their learning achievement seen from Sig. 2 tailed $0.000<0.005$. The that relationship distribution is positive seen from pearson correlations of motivation is 1 . The pearson correlation of achievement is 0.580 that mean Medium Correlation seen from Correlation Degree below ;

According to Correlations degree

Pearson Correlation Value $0.21 \mathrm{~s} / \mathrm{d} 40=$ Less Correlation

Pearson Correlation Value $0.41 \mathrm{~s} / \mathrm{d} 0.60=$ Medium Correlation

Pearson Correlation Value $0.61 \mathrm{~s} / \mathrm{d} 0.80=$ Strong Correlation

Pearson Correlation Value $0.81 \mathrm{~s} / \mathrm{d} 1.00=$ Perfect Correlation

Source : $\underline{w w w . s p s s i n d o n e s i a . c o m}$

\section{Discussion}

The result of corelation between student motivation and their English learning achievement follow the motivation and English learning achievement were significantly positive relationship correlated with each other. This result of the study indicate that there was positive relationship between student motivation and their learning achievement. This study showed that there is positive relation between student motivation and their learning achievement because their $r$ is 0.580 . the corelation is significant because the observed $\mathrm{r}(0.580)$ is greater than critical $\mathrm{r}$ (0.270) at the significance level of the 0.01 level (2-tailed). The shared vriance or $r^{2}$ is 0.3364 means that students learning achievment is accounted for by students learning motivation.

\section{CONCLUSION}

Based on analyzed it showed there are any relationship between students' motivation and their learning achievement at Islamic Senior High School in Cimahi city where the writers used grade $\mathrm{XI}$ at Science major classes that consists of 88 students as respondents. The relationship seen from Sig. 2 tailed $0.000<0.005$ and the distribution of that relationship is positive. Based on the data pearson correlation of achievement is 0.580 that mean Medium Correlation. 


\section{ACKNOWLEDGMENTS}

Alhamdulillahi rabil 'alamin, the writer expresses his highest gratitude to Allah Subhanahu wa ta'ala for blessing, love, opportunity, health, and mercy to complete this article. In arranging this article, a lot of people have provide motivation, advice, and support for the writers thank you so much.

\section{REFERENCES}

Alizadeh, M. (2016). The Impact of Motivation on English Language Learning. International Journal of Research in English Education, 1, 12.

Asvio, N. Arpinus, S. (2017). The Influence of Learning Motivation and Learning Environment on Undergraduate Students' Learning Achievement of Management of Islamic Education Study Program of Iain Batusangkar in 2016. Noble International Journal of Social Sciences Research.

Choosri, C., \& Intharaksa, U. (2011). Relationship Between Motivation and Students' English Learning Achievement: A Study of the Second Year Vocational Certificate Level Hatyai Technical Collage Students. Relationship Between Motivation and Students' English Learning Achievement, 6.

Ellliot, A. J., \& Covington, M. (2001). Approach and Avoidance Motivation. Educational Psychology Review.

Et.al, G. (2007). Relationship Between English Learning Motivation Types and Self-Identity Changes Among Chinese Students. TESOL Quarterly, 41, 133-155.

Kaswan \& Suprijadi, D. (2014). Language Acquisition. Jakarta: Dapur Buku.

Kormos, J. \& Cszier, K. (2010). A Comparison of A Foreign Language Learning Motivation of Hungarian Dyslexic and Nondyslexic Students. International Jurnal of Applied Linguistics, 20, 232-250.

Leedy, P. D. (1993). Practical Research : Planning and Design. New Jersey: Prentice-Hall.

Makmum, A. S. (2000). Psikologi Kependidikan. Bandung: PT. Remaja Rosda Karya.

Nicholson, S. J. (2015). English as An International Language: A Functional Role in South Korea. Journal for Study of English Linguistics, 14.

Panggabean, H. (2007). How To Motivate English Learners Faced With Physicological Burden. Surabaya: Petra Chistian University.

Panggabean, H. (2015). Problematic Approach to English Learning and Teaching: A Case in Indonesia. Canadian Center of Science and Education.

Poerwanto, N. (2007). Educational Psychology. Bandung: PT. Rosda Karya.

Smith, L. (1976). English as An International Auxiliary Language. RELC Journal. Retrieved from http://dx.doi.org/10.1177/003368827600700205

Suprijono, A. (2009). Cooperative Learning Teori dan Aplikasi PAIKEM. Yogyakarta: Pustaka Pelajar.

Tu'u, T. (2004). The Role of Discipline on Behavior and Students Achievement. Jakarta: Grasindo.

Winkel, W. S. (2003). Educational Psychology and Learning Evaulation. Jakarta: Gramedia. 